Vol IV. No.1, September 2019, hlm. 23-32

Available online at www.jurnal.una.ac.id/indeks/jmp

\title{
PENINGKATAN HASIL BELAJAR DAN MOTIVASI BELAJAR SISWA SEKOLAH DASAR MELALUI MEDIA PEMBELAJARAN MONOPOLI MATEMATIKA (MONOTIKA)
}

\author{
Mustika Fitri Larasati Sibuea ${ }^{1}$, Masitah Handayani ${ }^{2}$ \\ Program Studi Sistem Informasi, STMIK ROYAL Kisaran \\ Email : ${ }^{1}$ bukmus.inaction@gmail.com, ${ }^{2}$ bunga_fairuz@yahoo.com
}

\begin{abstract}
This study aims to find out whether using monopoly mathematics learning media (Monotica) can improve learning outcomes and student motivation. This research is an experimental research. The samples in this study were grade III students at Tamansiswa Sukadamai Elementary School and third grade students at Tamansiswa Sidodadi Elementary School. This study uses two types of instruments namely learning outcomes tests in the form of essay tests and learning motivation questionnaires. Before learning, the average learning outcomes of students who obtained problem-based learning using Monotica media (experimental class) was only 21.375, while the average value of student learning outcomes that obtained normal learning (control class) with an average of 21.267. After learning, an increase in the average learning outcomes of the two groups of students. For the experimental class the average learning outcome was 40.3125, while for the control class the average learning outcome was 37.867. Based on the calculation results obtained $t_{\text {count }}=3.45$ and $t_{\text {table }}=1.67$, so $t_{\text {count }}>t_{\text {table }}$ at a significance level of $\alpha$ of 0.05. Thus, the learning outcomes of the experimental class students differed from those of the control class. For learning motivation, before learning the average motivation of students studying the experimental class was only 49.19, while the average value of learning motivation of control class students was 49.07. After learning, the average motivation of learning in the experimental class is 50.91, while the average motivation for learning in the control class is 50.77. Based on the calculation results obtained $t_{\text {count }}=$ 2.48 and $t_{\text {table }}=1.69$, so $t_{\text {count }}>t_{\text {table }}$ at a significance level of $\alpha$ of 0.05 . Thus, the learning motivation of experimental class students has a difference with the learning motivation of control class students.
\end{abstract}

Keywords: learning outcomes, learning motivation, mathematics monopoly learning media

Abstrak
Penelitian ini bertujuan untuk mengetahui apakah dengan menggunakan media
pembelajaran monopoli matematika (Monotika) dapat meningkatkan hasil belajar dan
motivasi belajar siswa. Penelitian ini merupakan Penelitian Eksperimen. Yang menjadi
sampel dalam penelitian ini adalah siswa kelas III SD Tamansiswa Sukadamai dan siswa
kelas III SD Tamansiswa Sidodadi. Penelitian ini menggunakan dua jenis instrumen yaitu
tes hasil belajar dalam bentuk essay tes dan angket motivasi belajar. Sebelum
pembelajaran, rata-rata hasil belajar siswa yang memperoleh pembelajaran berbasis
masalah menggunakan media Monotika (kelas eksperimen) hanya sebesar 21,375 ,
sedangkan nilai rata-rata hasil belajar siswa yang memperoleh pembelajaran biasa (kelas
kontrol) dengan rata-rata sebesar 21,267 . Setelah pembelajaran, terjadi peningkatan rata-
rata hasil belajar kedua kelompok siswa tersebut. Untuk kelas eksperimen rata-rata hasil
belajar sebesar 40,3125, sementara untuk kelas kontrol mendapatkan rata-rata hasil
belajar sebesar 37,867 . Berdasarkan hasil perhitungan diperoleh thitung $=3,45$ dan $t_{\text {tabel }}=$
1,67, sehingga $t_{\text {hitung }}>t_{\text {tabel }}$ pada taraf signifikansi $\alpha$ sebesar 0,05 . Dengan demikian, hasil
belajar siswa kelas eksperimen memiliki perbedaan dengan hasil belajar siswa kelas 
Vol IV. No.1, September 2019, hlm. 23-32

Available online at www.jurnal.una.ac.id/indeks/jmp

kontrol. Untuk motivasi belajar, sebelum pembelajaran rata-rata motivasi belajar siswa kelas eksperimen hanya sebesar 49,19, sedangkan nilai rata-rata motivasi belajar siswa kelas kontrol sebesar 49,07. Setelah pembelajaran, rata-rata motivasi belajar kelas eksperimen sebesar 50,91, sementara rata-rata motivasi belajar kelas kontrol sebesar 50,77. Berdasarkan hasil perhitungan diperoleh $\mathrm{t}_{\text {hitung }}=2,48$ dan $\mathrm{t}_{\text {tabel }}=1,69$, sehingga $t_{\text {hitung }}>t_{\text {tabel }}$ pada taraf signifikansi $\alpha$ sebesar 0,05. Dengan demikian, motivasi belajar siswa kelas eksperimen memiliki perbedaan dengan motivasi belajar siswa kelas kontrol.

Kata Kunci: hasil belajar, motivasi belajar, media pembelajaran monopoli matematika

\section{PENDAHULUAN}

Matematika merupakan salah satu ilmu pengetahuan memberikan kontribusi yang sangat besar, mulai dari yang sederhana sampai yang kompleks, mulai dari yang abstrak sampai yang konkrit untuk pemecahan masalah dalam segala bidang. Akan tetapi bukan rahasia lagi bahwa banyak siswa yang tidak menyukai matematika. Mereka menganggap bahwa matematika sulit dipelajari serta gurunya kebanyakan tidak menyenangkan, membosankan, menakutkan, angker, dan sebagainya. Sikap ini tentu saja mengakibatkan motivasi dan hasil belajar matematika siswa tersebut menjadi rendah (Soegeng, 2013).

Menurut Jannah (2013) faktor yang menyebabkan kurang optimalnya pemahaman siswa dan motivasi siswa yaitu selain karena kemampuan siswa dan kesadaran siswa itu sendiri juga kemampuan guru dalam memilih media pembelajaran. Salah satu upaya yang dapat dilakukan adalah melalui media pembelajaran yang kreatif untuk mengubah motivasi siswa agar menyukai pelajaran matematika. Media dapat dijadikan sebagai sarana guru dalam menyampaikan materi. Salah satu media yang dapat digunakan adalah media pembelajaran dalam bentuk permainan seperti monopoli.
Monopoli adalah permainan papan yang sudah dikenal oleh anakanak dan berbagai kalangan. Penelitian yang dilakukan oleh Soegeng (2013) menjelaskan bahwa permainan monopoli dapat meningkatkan kemampuan kognitif anak dalam memahami konsep bilangan. Dalam penelitiannya tersebut media monopoli pada materi operasi matematika yang dibahas adalah hanya operasi penjumlahan dan pengurangan. Sedangkan pengembangan media monopoli yang akan peneliti lakukan yaitu untuk operasi tambah, kurang, kali dan bagi.

Berdasarkan dari uraian masalah di atas, peneliti memiliki ketertarikan untuk menciptakan media pembelajaran yang dapat memecahkan permasalah di atas. Media yang dimaksud yaitu media Monopoli Matematika. Melalui media Monopoli Matematika akan membantu siswa dalam penguasaan operasi jumlah, kurang, kali dan bagi.

\section{Media Pembelajaran}

Menurut Affandi (2015) media pembelajaran sebagai segala sesuatu perantara yang akan menyampaikan informasi dari guru ke siswa dalam suatu proses pembelajaran. Media pembelajaran 
Jurnal

MATEMATICS PAEDAGOGIC

Vol IV. No.1, September 2019, hlm. 23-32

Available online at www.jurnal.una.ac.id/indeks/jmp

berfungsi merangsang pikiran, perasaan, perhatian dan minat siswa sehingga proses pembelajran dapat berjalan dengan baik. Media diartikan sebagai perantara penyampaian informasi dari sumber ke penerima.

\section{Operasi Aljabar}

pokok $\begin{array}{rcr}\text { Aljabar merupakan } & \text { materi } \\ \text { dang } & \text { penting } & \text { dalam }\end{array}$ matematika karena digunakan dalam berbagai materi pokok yang lainya. Operasi hitung merupakan bekal dasar yang hendaknya dimiliki dalam mempelajari materi aljabar. Materi operasi hitung bentuk aljabar juga berkaitan dengan penerapan aljabar dalam kehidupan sehari-hari. Maka dari itu penguasaan terhadap operasi aljabar penting karena sebagai bekal keterampilan untuk penguasaan materi aljabar yang selanjutnya. Keterampilan dalam penguasaan materi aljabar tersebut akan berdampak pada hasil belajar siswa (Nurlita, 2016). Dalam konteks ini yang dimaksud dengan operasi hitung matematika adalah operasi tambah, kurang, kali dan bagi.

\section{Hasil Belajar}

Menurut Sembiring (2018) hasil belajar itu adalah suatu hasil nyata yang dicapai oleh siswa dalam usaha menguasai kecakapan jasmani dan rohani di sekolah yang diwujudkan dalam bentuk raport pada setiap semester. Hasil belajar merupakan aspek utama yang harus dicapai dalam pembelajaran.

\section{Motivasi Belajar}

Aspek lain yang harus diperhatikan oleh guru dalam pembelajaran adalah motivasi belajar siswa. Motivasi adalah suatu keadaan dalam diri individu yang menyebabkan seseorang melakukan kegiatan tertentu untuk mencapai tujuan (Mappeasse, 2009).

\section{METODE PENELITIAN}

Penelitian ini dilaksanakan pada semester genap tahun ajaran 2018/2019. Yang menjadi populasi penelitian ini adalah siswa kelas III SD Tamansiswa Sukadamai dan SD Tamansiswa Sidodadi. Penelitian akan dilakukan terhadap dua kelas sampel representatif yang terpilih secara acak dari populasi. Satu untuk kelas eksperimen dan satu untuk kelas kontrol. Jenis penelitian ini adalah penelitian eksperimen dengan menerapkan pembelajaran berbasis masalah.

Istilah Pembelajaran Berbasis Masalah (PBM) diadopsi dari istilah Inggris Problem Based Instruction (PBI). Model pembelajaran berbasis masalah ini telah dikenal sejak zaman John Dewey. Pengajaran berbasis masalah adalah suatu pendekatan pengajaran yang menggunakan masalah dunia nyata sebagai suatu konteks bagi siswa untuk belajar tentang cara berfikir kritis dan keterampilan pemecahan masalah. 
Vol IV. No.1, September 2019, hlm. 23-32

Available online at www.jurnal.una.ac.id/indeks/jmp

Tabel 1. Sintaks Model Pembelajaran Berbasis Masalah

\begin{tabular}{|c|c|}
\hline & \\
\hline $\begin{array}{l}\text { Orientasi siswa pada } \\
\text { masalah }\end{array}$ & $\begin{array}{ll}\text { 1. } & \text { Guru me } \\
\text { 2. Menjelas } \\
\text { 3. Memotiv } \\
\text { masalah }\end{array}$ \\
\hline $\begin{array}{l}\text { Mengorganisasikan } \\
\text { siswa untuk belajar }\end{array}$ & $\begin{array}{l}\text { 4. Guru } r \\
\text { mengorg } \\
\text { dengan } n\end{array}$ \\
\hline $\begin{array}{l}\text { Membimbing } \\
\text { penyelidikan } \\
\text { individu maupun } \\
\text { kelompok }\end{array}$ & $\begin{array}{l}\text { 5. Guru } \mathrm{m} \\
\text { informas } \\
\text { untuk r } \\
\text { masalah. }\end{array}$ \\
\hline $\begin{array}{l}\text { Mengembangkan } \\
\text { dan menyajikan } \\
\text { hasil karya }\end{array}$ & $\begin{array}{l}\text { 6. Guru m } \\
\text { menyiap } \\
\text { video, }\end{array}$ \\
\hline $\begin{array}{l}\text { Menganalisis dan } \\
\text { mengevaluasi } \\
\text { proses pemecahan } \\
\text { masalah }\end{array}$ & $\begin{array}{l}\text { 7. Guru m } \\
\text { atau eva } \\
\text { proses-p }\end{array}$ \\
\hline Sumber: Tri & $9: 98)$ \\
\hline $\begin{array}{l}\text { Instrumen yang } \\
\text { dalam penelitian ini } \\
\text { hasil belajar dalam b } \\
\text { tes dan angket moti } \\
\text { Dalam penelitian i } \\
\text { angket diberikan } \\
\text { pembelajaran. Tes da } \\
\text { digunakan untuk n } \\
\text { data hasil belajar d } \\
\text { belajar siswa. }\end{array}$ & $\begin{array}{l}\text { digunakan } \\
\text { adalah tes } \\
\text { entuk essay } \\
\text { asi belajar. } \\
\text { i tes dan } \\
\text { ada akhir } \\
\text { angket ini } \\
\text { endapatkan } \\
\text { in motivasi }\end{array}$ \\
\hline
\end{tabular}

\section{HASIL PENELITIAN}

Hasil Belajar Siswa

Data hasil belajar siswa kelas eksperimen (yang diajarkan dengan pembelajaran berbasis masalah) menggunakan media pembelajaran Monopoli

\section{KEGIATAN GURU}

kan tujuan pembelajaran.

an logistik yang dibutuhkan.

yang dipilih.

membantu siswa mendefinisikan dan isasikan tugas belajar yang berhubungan alah tersebut.

endorong siswa untuk mengumpulkan yang sesuai, melaksanakan eksperimen, pejelasan dan pemecahan

embantu siswa dalam merencanakan dan 
Jurnal

MATEMATICS PAEDAGOGIC

Vol IV. No.1, September 2019, hlm. 23-32

Available online at www.jurnal.una.ac.id/indeks/jmp

Tabel 2. Deskripsi Analisis Data Hasil

Belajar Siswa Kedua Kelompok

Pembelajaran

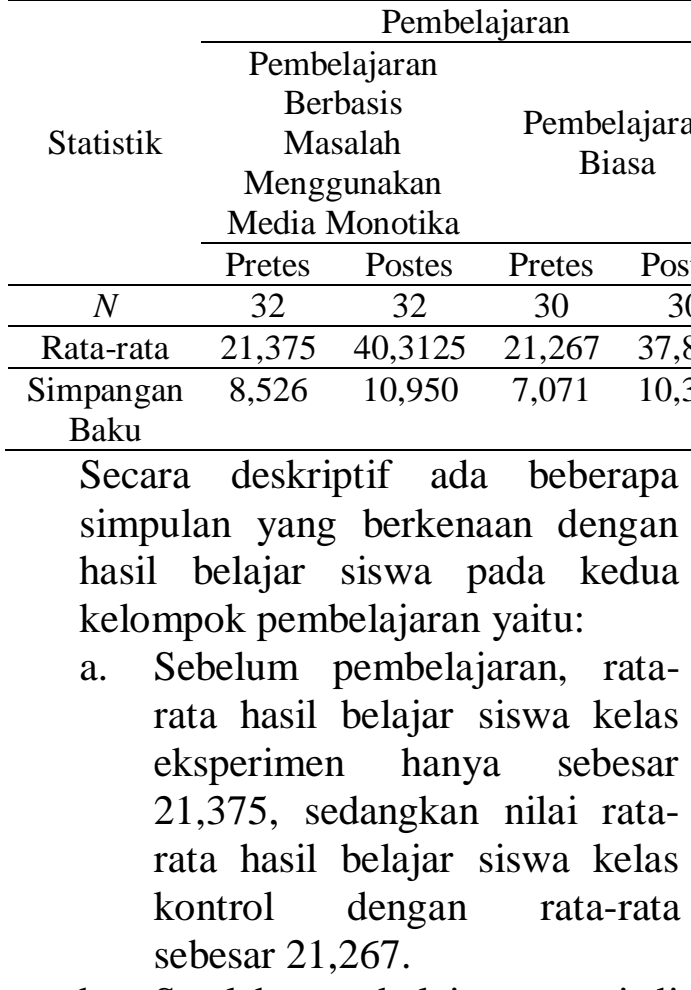

b. Setelah pembelajaran, terjadi peningkatan rata-rata hasil belajar kedua kelompok siswa tersebut. Siswa kelas eksperimen mendapatkan ratarata hasil belajar sebesar 40,3125, sementara siswa yang memperoleh pembelajaran biasa mendapatkan rata-rata hasil belajar sebesar 37,867.

Adapun uji persyaratan analisis data yang dilakukan dalam penelitian adalah uji normalitas dan uji homogenitas.

\section{Uji Normalitas}

Uji normalitas data menggunakan uji Liliefors dengan hipotesis nol (Ho) yang menyatakan bahwa sampel berasal dari populasi berdistribusi normal.
Berikut ini hasil uji normalitas data pada kelas eksperimen dan kelas kontrol dapat dilihat pada tabel 3.

Tabel 3. Rangkuman Uji

Normalitas Data dengan Uji Liliefors

\begin{tabular}{ccccc}
\hline Data & Kelas & $L_{\text {hitung }}$ & $L_{\text {tabel }}$ & $\begin{array}{c}\text { Kesim } \\
\text { pulan }\end{array}$ \\
\hline Pretes & Eksprimen & 0,112 & 0,157 & Normal \\
\hline Pretes & Kontrol & 0,097 & 0,161 & Normal \\
\hline Postes & Eksprimen & 0,137 & 0,157 & Normal \\
\hline Postes & Kontrol & 0,108 & 0,161 & Normal \\
\hline
\end{tabular}

Berdasarkan tabel 2. dapat dilihat bahwa hasil uji normalitas data pretes pada kelas eksperimen diperoleh $\mathrm{L}_{\text {hitung }}<\mathrm{L}_{\text {tabel }}(0,112<$ 0,157), dan pada kelas kontrol juga diperoleh $\mathrm{L}_{\text {hitung }}<\mathrm{L}_{\text {tabel }}(0,097<$ $0,162)$. Hal serupa juga terjadi pada hasil uji normalitas data postes kelas ekperimen dengan $\mathrm{L}_{\text {hitung }}<$ $\mathrm{L}_{\text {tabel }}(0,137<0,157)$, dan pada kelas kontrol diperoleh $\mathrm{L}_{\text {hitung }}<$ $\mathrm{L}_{\text {tabel }}(0,107<0,161)$. Dengan demikian data postes dan pretes pada kelas eksperimen maupun kelas kontrol berdistribusi normal pada taraf signifikansi $\alpha$ sebesar 0,05 .

\section{Uji Homogenitas}

Uji homogenitas data menggunakan uji Fisher. Uji homogenitas ini dilakukan untuk mengetahui apakah data bersifat homogen atau tidak yang dilihat berdasarkan pada perbandingan harga $F_{\text {hitung }}$ dengan $F_{\text {tabel }}$ pada taraf signifikansi $\alpha$ sebesar 0,05. Apabila $F_{\text {hitung }}<\mathrm{F}_{\text {tabel }}$ maka data tersebut memiliki varians yang sama atau homogen. Berikut ini hasil uji homogenitas data pada kelas 
Jurnal

MATEMATICS PAEDAGOGIC

Vol IV. No.1, September 2019, hlm. 23-32

Available online at www.jurnal.una.ac.id/indeks/jmp

ekperimen dan kelas kontrol dapat dilihat pada tabel 4 .

Tabel 4. Rangkuman Uji

Homogenitas Data dengan Uji

Fisher

\begin{tabular}{|c|c|c|c|c|}
\hline Data & Kelas & $\begin{array}{c}F_{\text {hitun }} \\
g\end{array}$ & $F_{\text {tabel }}$ & $\begin{array}{c}\text { Kesimpula } \\
n\end{array}$ \\
\hline Pretes & $\begin{array}{c}\text { Eksperimen } \\
\text { Kontrol }\end{array}$ & 0,93 & 1,85 & Homogen $\mathrm{p}$ \\
\hline Postes & $\begin{array}{c}\text { Eksperimen } \\
\text { Kontrol }\end{array}$ & 0,72 & 1,85 & Homogen $\mathrm{t}$ \\
\hline
\end{tabular}

Berdasarkan tabel 4. dapat dilihat bahwa hasil uji homogenitas data pretes pada kelas eksperimen dan kelas kontrol diperoleh $\mathrm{F}_{\text {hitung }}<$ $F_{\text {tabel }}(0,93<1,85)$, maka data pretes pada kedua kelas tersebut memiliki varians yang sama atau homogen. Kemudian pada uji homogenitas data postes pada kelas eksperimen dan kelas kontrol juga diperoleh $F_{\text {hitung }}<F_{\text {tabel }}(0,72<$ 1,85), maka dapat pula disimpulkan bahwa data postes pada kedua kelas tersebut memiliki varians yang sama atau homogen.

\section{Pengujian Hipotesis Uji t Pretes}

Uji $t$ dilakukan untuk mengetahui apakah terdapat perbedaan kemampuan awal siswa pada kelas kontrol dan kelas eksperimen. Berdasarkan hasil perhitungan diperoleh $t_{\text {hitung }}=0,98$ dan $t_{\text {tabel }}=1,67$, sehingga $t_{\text {hitung }}<$ $t_{\text {tabel }}$ pada taraf signifikansi $\alpha$ sebesar 0,05. Berdasarkan hasil tersebut, maka thitung masih berada pada daerah penerimaan Ho atau dengan kata lain tidak terdapat perbedaan yang signifikan antara kemampuan awal siswa pada kelas

kontrol dan kelas eksperimen pada taraf signifikansi 5\%. Dengan demikian, siswa pada kelas kontrol dan kelas eksperimen memiliki kemampuan awal yang cenderung sama pada materi operasi aljabar.

\section{Uji t Postes}

Berdasarkan

hasil perhitungan diperoleh $t_{\text {hitung }}=3,45$ dan $t_{\text {tabel }}=1,67$, sehingga $t_{\text {hitung }}>$ $t_{\text {tabel }}$ pada taraf signifikansi $\alpha$ sebesar 0,05. Berdasarkan hasil tersebut, maka Ho ditolak dan Ha diterima atau dengan kata lain terdapat perbedaan yang signifikan antara hasil belajar siswa pada kelas kontrol dan kelas eksperimen pada taraf signifikansi 5\%. Dengan demikian, hasil belajar siswa yang diajarkan dengan pembelajaran berbasis masalah menggunakan media pembelajaran Monopoli Matematika (Monotika) memiliki perbedaan dengan hasil belajar siswa yang diajarkan dengan Pembelajaran Biasa.

\section{Motivasi Belajar Siswa}

Berikut ini data hasil analisis deskriptif motivasi siswa kedua kelompok pembelajaran.

Tabel 5. Deskripsi Data Motivasi Belajar Siswa Kedua Kelompok Pembelajaran

\begin{tabular}{|c|c|c|c|c|}
\hline \multirow{3}{*}{ Statistik } & \multicolumn{4}{|c|}{ Pembelajaran } \\
\hline & \multicolumn{2}{|c|}{$\begin{array}{c}\text { Pembelajaran Berbasis } \\
\text { Masalah Menggunakan } \\
\text { Media Monotika }\end{array}$} & \multicolumn{2}{|c|}{$\begin{array}{c}\text { Pembelajara } \\
\text { Biasa }\end{array}$} \\
\hline & Pretes & Postes & Pretes & Postes \\
\hline$N$ & 32 & 32 & 30 & 30 \\
\hline Rata-rata & 49,19 & 50,91 & 49,07 & 50,77 \\
\hline $\begin{array}{l}\text { Simpang } \\
\text { an Baku }\end{array}$ & 0,821 & 0,641 & 0,87 & 0,774 \\
\hline
\end{tabular}


Jurnal

MATEMATICS PAEDAGOGIC

Vol IV. No.1, September 2019, hlm. 23-32

Available online at www.jurnal.una.ac.id/indeks/jmp

dengan motivasi belajar siswa pada kedua kelompok pembelajaran yaitu:

a. Sebelum pembelajaran, ratarata motivasi belajar siswa kelas eksperimen hanya sebesar 49,19, sedangkan nilai rata-rata motivasi belajar siswa kelas kontrol sebesar 49,07.

b. Setelah pembelajaran, terjadi peningkatan rata-rata motivasi belajar kedua kelompok siswa tersebut. Siswa kelas eksperimen mendapatkan ratarata motivasi belajar sebesar 50,91, sementara siswa kelas kontrol mendapatkan rata-rata motivasi belajar sebesar 50,77.

\section{Uji Normalitas}

Berikut ini hasil uji normalitas data pada kelas eksperimen dan kelas control dapat dilihat pada tabel 6 .

Tabel 6. Rangkuman Uji Normalitas Data dengan Uji Liliefors

\begin{tabular}{ccccc}
\hline Data & Kelas & $L_{\text {hitung }}$ & $L_{\text {tabel }}$ & $\begin{array}{c}\text { Kesim } \\
\text { pulan }\end{array}$ \\
\hline Pretes & Eksprimen & 0,103 & 0,159 & Normal \\
\hline Pretes & Kontrol & 0,087 & 0,162 & Normal \\
\hline Postes & Eksprimen & 0,132 & 0,159 & Normal \\
\hline Postes & Kontrol & 0,115 & 0,162 & Normal \\
\hline
\end{tabular}

Berdasarkan tabel 6. dapat dilihat bahwa hasil uji normalitas data pretes pada kelas eksperimen diperoleh $\mathrm{L}_{\text {hitung }}<\mathrm{L}_{\text {tabel }}(0,103<$ 0,159), dan pada kelas kontrol juga diperoleh $\mathrm{L}_{\text {hitung }}<\mathrm{L}_{\text {tabel }}(0,087<$ $0,162)$. Hal serupa juga terjadi pada hasil uji normalitas data postes kelas ekperimen dengan $\mathrm{L}_{\text {hitung }}<$ $\mathrm{L}_{\text {tabel }}(0,132<0,159)$, dan pada kelas kontrol diperoleh $\mathrm{L}_{\text {hitung }}<$ $\mathrm{L}_{\text {tabel }}(0,115<0,162)$. Dengan demikian data postes dan pretes pada kelas eksperimen maupun kelas kontrol berdistribusi normal pada taraf signifikansi $\alpha$ sebesar 0,05 .

\section{Uji Homogenitas}

Uji homogenitas data menggunakan uji Fisher. Uji homogenitas ini dilakukan untuk mengetahui apakah data bersifat homogen atau tidak yang dilihat berdasarkan pada perbandingan harga $F_{\text {hitung }}$ dengan $F_{\text {tabel }}$ pada taraf signifikansi $\alpha$ sebesar 0,05. Apabila $F_{\text {hitung }}<\mathrm{F}_{\text {tabel }}$ maka data tersebut memiliki varians yang sama atau homogen. Rangkuman hasil uji homogenitas data pada kelas ekperimen dan kelas kontrol dapat dilihat pada tabel 7 .

Tabel 7. Rangkuman Uji

Homogenitas Data dengan Uji Fisher

\begin{tabular}{|c|c|c|c|c|}
\hline Data & Kelas & $F_{\text {hitung }}$ & $F_{\text {tabel }}$ & $\begin{array}{c}\text { Kesimpul } \\
\text { an }\end{array}$ \\
\hline Pretes & $\frac{\text { Ekspe }}{\text { Kor }}$ & 0,86 & 1,85 & Homogen \\
\hline Postes & $\begin{array}{c}\text { Eksperimen } \\
\text { Kontrol }\end{array}$ & 0,03 & 1,85 & Homogen \\
\hline
\end{tabular}

Berdasarkan tabel 7. dapat dilihat bahwa hasil uji homogenitas data pretes pada kelas eksperimen dan kelas kontrol diperoleh $\mathrm{F}_{\text {hitung }}<$ $F_{\text {tabel }}(0,86<1,85)$, maka data pretes pada kedua kelas tersebut memiliki varians yang sama atau homogen. Kemudian pada uji homogenitas data postes pada kelas eksperimen dan kelas kontrol juga diperoleh $F_{\text {hitung }}<F_{\text {tabel }}(0,63<$ 1,85), maka dapat pula disimpulkan 
Jurnal

MATEMATICS PAEDAGOGIC

Vol IV. No.1, September 2019, hlm. 23-32

Available online at www.jurnal.una.ac.id/indeks/jmp

bahwa data postes pada kedua kelas tersebut memiliki varians yang sama atau homogen.

\section{Pengujian Hipotesis}

\section{Uji t Pretes}

Uji t dilakukan untuk
mengetahui $\begin{array}{r}\text { apakah terdapat } \\ \text { perbedaan motivasi awal siswa }\end{array}$
pada kelas kontrol dan kelas
eksperimen. Berdasarkan hasil
perhitungan diperoleh thitung $=0,76$
dan $\mathrm{t}_{\text {tabel }}=1,59$, sehingga thitung
$\mathrm{t}_{\text {tabel pada taraf signifikansi } \alpha}$
sebesar 0,05. Berdasarkan hasil
tersebut, maka thitung masih berada
pada daerah penerimaan Ho atau
dengan kata lain tidak terdapat
perbedaan yang signifikan antara
motivasi awal siswa pada kelas
kontrol dan kelas eksperimen pada
taraf signifikansi 5\%. Dengan
demikian, siswa pada kelas kontrol
dan kelas eksperimen memiliki
motivasi awal yang cenderung
sama pada materi operasi aljabar.

\section{Uji t Postes}

Berdasarkan hasil perhitungan diperoleh $t_{\text {hitung }}=2,48$ dan $t_{\text {tabel }}=1,69$, sehingga $t_{\text {hitung }}>$ $t_{\text {tabel }}$ pada taraf signifikansi $\alpha$ sebesar 0,05. Berdasarkan hasil tersebut, maka Ho ditolak dan $\mathrm{Ha}$ diterima atau dengan kata lain terdapat perbedaan yang signifikan antara motivasi belajar siswa pada kelas kontrol dan kelas eksperimen pada taraf signifikansi 5\%. Dengan demikian, motivasi belajar siswa kelas eksperimen memiliki perbedaan dengan motivasi belajar siswa yang diajarkan dengan Pembelajaran Biasa.

\section{PEMBAHASAN PENELITIAN}

Hasil penelitian menunjukkan bahwa peningkatan hasil belajar dan motivasi belajar siswa yang diajarkan dengan pembelajaran berbasis masalah lebih tinggi daripada peningkatan hasil belajar dan motivasi belajar siswa yang memperoleh pembelajaran biasa. Hal ini dikarenakan pembelajaran berbasis masalah memiliki keunggulan dibandingkan dengan pembelajaran biasa.

Pembelajaran berbasis masalah adalah suatu pembelajaran yang membantu guru menciptakan lingkungan pembelajaran yang dimulai dengan masalah sehingga orientasi siswa pada masalah merupakan karakteristik pertama dari pembelajaran berbasis masalah. Runtutan kegiatan yang dilakukan siswa pada pembelajaran biasa akan membuat siswa tidak berperan aktif dalam pembelajaran. Siswa hanya menerima saja semua hal yang dijelaskan oleh guru.

\section{SIMPULAN}

Berdasarkan hasil penelitian, sebelum pembelajaran rata-rata hasil belajar siswa yang memperoleh pembelajaran berbasis masalah menggunakan media Monotika (kelas eksperimen) hanya sebesar 21,375, sedangkan nilai rata-rata hasil belajar siswa yang memperoleh pembelajaran biasa (kelas kontrol) dengan rata-rata sebesar 21,267. Setelah 
Jurnal

MATEMATICS PAEDAGOGIC

Vol IV. No.1, September 2019, hlm. 23-32

Available online at www.jurnal.una.ac.id/indeks/jmp

pembelajaran, terjadi peningkatan rata-rata hasil belajar kedua kelompok siswa tersebut. Untuk kelas eksperimen rata-rata hasil belajar sebesar 40,3125, sementara untuk kelas kontrol mendapatkan rata-rata hasil belajar sebesar 37,867. Berdasarkan hasil perhitungan diperoleh $t_{\text {hitung }}=3,45$ dan $\mathrm{t}_{\text {tabel }}=1,67$, sehingga $\mathrm{t}_{\text {hitung }}>$ $t_{\text {tabel }}$ pada taraf signifikansi $\alpha$ sebesar 0,05. Dengan demikian, hasil belajar siswa kelas eksperimen memiliki perbedaan dengan hasil belajar siswa kelas kontrol. Untuk motivasi belajar, sebelum pembelajaran rata-rata motivasi belajar siswa kelas eksperimen hanya sebesar 49,19, sedangkan nilai rata-rata motivasi belajar siswa kelas kontrol sebesar 49,07. Setelah pembelajaran, ratarata motivasi belajar kelas eksperimen sebesar 50,91,

\section{DAFTAR RUJUKAN}

Affandi, Rifki. 2015. Pengembangan Media Pembelajaran Ular Tangga Untuk Meningkatkan Motivasi belajar Siswa dan Hasil Belajar IPS di Sekolah Dasar. 2015. Jurnal inovasi Pembelajaran (JINoP). 1(1) : $77-89$

Jannah, M., Triyanto, \& Ekana, H. 2013. Penerapan Model Missouri Mathematic Project (MMP) Untuk Meningkatkan Pemahaman dan Sikap Positif Siswa Pada Materi Fungsi. Jurnal Pendidikan Matematika Solusi. 1 (1): $61-66$.

Mappeasse, M. Y. (2009). Pengaruh cara dan motivasi belajar terhadap sementara rata-rata motivasi belajar kelas kontrol sebesar 50,77. Berdasarkan hasil perhitungan diperoleh $t_{\text {hitung }}=2,48$ dan $t_{\text {tabel }}=$ 1,69 , sehingga $t_{\text {hitung }}>t_{\text {tabel }}$ pada taraf signifikansi $\alpha$ sebesar 0,05 . Dengan demikian, motivasi belajar siswa kelas eksperimen memiliki perbedaan dengan motivasi belajar siswa kelas kontrol.

\section{UCAPAN TERIMA KASIH}

Ucapan terima kasih sebesar-besarnya atas pendanaan penelitian dan publikasi yang dibiayai Direktorat Riset dan Pengabdian Masyarakat Direktorat Jenderal Penguatan Riset dan Pengabdian Kementerian Riset, Teknologi dan Pendidikan Tinggi Sesuai dengan Kontrak Penelitian Anggaran 2019.

hasil belajar programmable logic controller (PLC) siswa kelas III jurusan listrik SMK Negeri 5 Makassar. Jurnal Medtek, 1(2), 16.

Nurlita, dkk. 2016. Miskonsepsi Konsep Prasyarat Aljabar Mahasiswa Pendidikan Guru Madrasah Ibtidaiyah. Jurnal Didaktik Matematika. 3 (2) : 8595.

Sembiring, M. A., Sibuea, M. F. L., \& Sapta, A. (2018). Analisa Kinerja Algoritma C. 45 Dalam Memprediksi Hasil Belajar. JOURNAL OF SCIENCE AND SOCIAL RESEARCH, 1(1), 73-79. 
Jurnal

\section{MATEMATICS PAEDAGOGIC}

Vol IV. No.1, September 2019, hlm. 23-32

Available online at www.jurnal.una.ac.id/indeks/jmp

Soegeng, A. Y., \& Dewi, S. K. S. (2013). Keefektifan Metode Permainan Monopoli Materi Operasi Hitung Terhadap Minat dan Hasil Belajar Siswa Kelas I SD Negeri 1 Kedungsuren

Kendal. Malih Peddas (Majalah Ilmiah Pendidikan Dasar), 3(1).

Trianto. (2009). Mendesain Model Pembelajaran Inovatif Progresif. Jakarta: Kencana Prenada Media Group 